\title{
ANALISIS HUBUNGAN PENGELUARAN PENDI DI KAN DAN PERTUMBUHAN EKONOMI DENGAN MENGGUNAKAN PENDEKATAN KAUSALITAS GRANGER
}

\author{
Aula Ahmad Hafidh \\ Jurusan Pendidikan Ekonomi FE UNY
}

\begin{abstract}
Abstrak
Penelitian ini dimaksudkan untuk menganalisis hubungan antara pengeluaran pendidikan dan pertumbuhan ekonomi. Hal itu dilakukan apakah keduanya saling mempengaruhi atau hanya satu arah. Untuk mengetahuinya digunakan uji kausalitas Granger. Data yang dianalisis merupakan data time series tahunan dari tahun 1970-2008.

Setelah dianalisis dan diolah data diperoleh hasil bahwa kedua variabel penelitian mempunyai hubungan kausalitas artinya kedua variabel pengeluaran pendidikan dan pertumbuhan ekonomi saling mempengaruhi. Pengeluaran pemerintah dalam bidang pendidikan akan mempengaruhi pertumbuhan ekonomi, di sisi yang lain pertumbuhan ekonomi akan mempengaruhi pengeluaran pendidikan pula. Untuk mendapatkan pemahaman hubungan yang lebih baik, maka dianalisis bagaimana mekanisme transmisi variabel dalam mempengaruhi variabel lainnya. Alat analisis yang digunakan adalah Vector Autoregressive (VAR). Dari hasil regresi VAR, diperoleh hasil bahwa variabel pertumbuhan ekonomi mempengaruhi pengeluaran pendidikan pada lag ke 1, artinya ketika pertumbuhan ekonomi naik, maka pemerintah dapat meningkatkan pengeluarannya setahun berikutnya. Sedangkan pengeluaran pendidikan baru akan mempengaruhi pertumbuhan ekonomi pada lag ke 3, artinya pengeluaran pendidikan baru akan mempengaruhi pertumbuhan pada periode 3 tahun ke depan.
\end{abstract}

Kata Kunci: pengeluaran pendidikan, pertumbuhan ekonomi, Granger Causality Test, VAR

\section{A. Pendahuluan}

Sektor swasta sangat sulit diharapkan untuk berkontribusi lebih besar dalam menggerakkan perekonomian dengan kondisi-kondisi yang tidak mendukung. Rencana kenaikan tarif dasar listrik (TDL) pada tahun 2010 ini dan peningkatan upah minimum propinsi/ kabupaten/kota akan memperberat dunia usaha. Biaya operasional perusahaan akan meningkat, sementara itu daya beli masyarakat terasa terus mengalami penurunan. Di tengah sektor dunia usaha atau swasta yang seperti ini maka untuk memperbaiki dan meningkatkan produk domestik bruto diperlukan peran 
pemerintah yang lebih besar. Sesuai dengan pendapat Keynes, untuk mengatasi keadaan seperti ini maka sangat diperlukan campur tangan pemerintah dengan mempengaruhi permintaan agregat. Kebijakan pemerintah dapat dilakukan dua cara yaitu mempengaruhi permintaan agregat dan penawaran agregat. Kebijakan yang mempengaruhi penawaran agregat dilakukan lebih untuk mempengaruhi kondisi sektor riil melalui peraturan-peraturan. Hanya saja kebijakan ini akan efektif dalam jangka waktu yang agak lama dan akan lebih baik bila dilakukan dengan kebijakan moneter dan sektor riil. Sementara itu kebijakan yang mempengaruhi permintaan agregat dilakukan melalui pengeluaran pemerintah (Anggaran Pendapatan dan Belanja Negara/APBN). Kebijakan ini efektif dalam waktu yang tidak lama karena pemerintah sendiri sebagai pemberi kebijakan dan sekaligus pelaku. Dalam perspektif lain kebijakan ini dikenal dengan kebijakan fiskal.

Sejak Januari 2001 bangsa Indonesia melalui babak baru penyelenggaraan pemerintahan, di mana Otonomi daerah dilaksanakan di seluruh Dati II (kota dan kabupaten) yang jumlahnya mencapai 336. Hal ini menimbulkan peningkatan tanggung jawab penyelenggaraan pemerintahan (penyediaan barang publik dan pembangunan ekonomi) di tingkat daerah yang sangat besar, khususnya pada bidang pendidikan yang merupakan unsur esensial dalam pembangunan daerah dan telah menjadi salah satu bagian utama kebutuhan penduduk. Namun, kemampuan daerah untuk mempertahankan dan meningkatkan penyelenggaraan pendidikan tersebut dapat dikatakan sangat terbatas, mengingat peran Pendapatan Asli Daerah (PAD) masih rendah dalam penerimaan APBD daerah kota/kabupaten dan kesiapan sumber daya manusia (SDM) serta kemampuan manajemen sektor pendidikan tingkat daerah masih terbatas.

Secara umum diyakini desentralisasi fiskal akan meningkatkan kesejahteraan masyarakat. Pendapat ini dilandasi oleh pandangan yang menyatakan kebutuhan masyarakat daerah terhadap pendidikan dan barang publik pada umumnya akan terpenuhi dengan lebih baik dibandingkan bila langsung diatur oleh pemerintah pusat. Namun kecenderungan ke arah tersebut tidak tampak karena hingga saat ini sebagian besar Pemerintah Daerah (Pemda dan DPRD) Kota dan Kabupaten di Indonesia merespon desentralisasi fiskal dengan menggenjot kenaikan PAD melalui pajak dan restribusi tanpa diimbangi peningkatan efektivitas pengeluaran APBD. Langkah kebijakan semacam ini dapat berpengaruh buruk terhadap penyelenggaraan pendidikan di tingkat daerah serta kesejahteraan masyarakatnya.

Mengingat kepentingan di atas, maka patut dipertanyakan hingga sejauh mana pelaksanaan desentralisasi fiskal dapat menimbulkan implikasi buruk terhadap 
aktivitas penyelenggaraan pendidikan di daerah kota dan Kabupaten di Indonesia. Kebijakan fiskal melalui pengeluaran pemerintah dalam APBN diharapkan dapat menstimulus produk domestik bruto. Pengeluaran pemerintah dapat menstimulus perekonomian melalui peningkatan konsumsi dan investasi. Konsumsi dan investasi merupakan komponen Produk Domestik Bruto (PDB). Seperti kita ketahui dalam konsep makroekonomi dan pembangunan ekonomi bahwa $\mathrm{PDB}(\mathrm{Y})$ terdiri dari konsumsi rumah tangga $(C)$, investasi $(\mathrm{I})$, pengeluaran pemerintah $(\mathrm{G})$ dan net ekspor (X-M) atau $(\mathrm{Y}=\mathrm{C}+\mathrm{I}+\mathrm{G}+(\mathrm{X}-\mathrm{M}))$. Pengeluaran rutin pemerintah digunakan untuk pengeluaran yang tidak produktif dan mengarah kepada konsumsi sedang pengeluaran pembangunan lebih bersifat investasi.

Pengeluaran pendidikan sebagai variabel dependen, Artinya produk domestik bruto mempengaruhi pengeluaran pendidikan. Teori perkembangan pengeluaran pemerintah yang telah diuraikan di atas menunjukkan bahwa produk domestik bruto (PDB) akan mempengaruhi besarnya pengeluaran pendidikan. Pengeluaran pendidikan sebagai variabel independen, Artinya pengeluaran pendidikan mempengaruhi produk domestik bruto (PDB). John Due(1968) mengemukakan bahwa pemerintah dapat mempengaruhi tingkat PDB nyata dengan mengubah persediaan berbagai faktor yang dapat dipakai dalam produksi melalui program-program pengeluaran pemerintah seperti pendidikan. Sementara Atep Adya Barata(2004) mengatakan bahwa kegiatan yang dilakukan pemerintah yang mendorong besaran jumlah pengeluaran negara mempunyai pengaruh terhadap perekonomian masyarakat. Landau (1986) membuktikan bahwa pengeluaran pemerintah di bidang militer dan pendidikan berkorelasi negatif terhadap pertumbuhan ekonomi, sementara untuk pendidikan sendiri berkorelasi kuat dan investasi pemerintah berkorelasi positif tetapi tidak signifikan. Steven A.Y. Lin (1994) mengatakan bahwa pengeluaran pemerintah akan meningkatkan pertumbuhan ekonomi (PDB) dengan laju yang semakin mengecil. Lin juga menyatakan bahwa Hukum Wagner hanya berlaku untuk negara maju.

Pengeluaran pemerintah di bidang pendidikan yang relatif besar mutlak dilakukan terutama untuk mengejar ketertinggalan pendidikan negara Indonesia dengan negara-negara lain. Selain itu peningkatan pendidikan akan membawa dampak yang positif terhadap penurunan kemiskinan, peningkatan kesejahteraan penduduk serta dampak positif lainnya. Menurut Sylwester (2002) negara yang mencurahkan banyak perhatian terhadap public education (dilihat dari persentase GNP terhadap pendidikan) mempunyai tingkat ketimpangan pendapatan yang rendah. Hasil penelitian ini memperkuat studi sebelumnya yang dilakukan oleh Easterly dan Rebello (1993) dan Sylwester (1999) yang mengatakan bahwa pengeluaran pendidikan tidak hanya 
berhubungan dengan pertumbuhan ekonomi tetapi juga mengurangi ketimpangan pendapatan.

Penelitian mengenai sumber-sumber pertumbuhan ekonomi suatu negara dengan memasukkan variabel human capital sudah banyak dilakukan, antara lain adalah Mankiw, Romer dan Weil (1992), dengan menggunakan data cross section dari berbagai negara yang diperoleh dari UNESCO Yearbook. Ranis, Stewart dan Ramirez (2000) meneliti hubungan antara economic growth dan human development dalam bentuk hubungan dua rantai. Bayhaqi (2000) menggunakan tiga formulasi model yang memperlihatkan total faktor produksi (TFP) pertumbuhan Indonesia selama tahun 1969-1998. Wang dan Yao (2002) meneliti sumber pertumbuhan ekonomi Cina dengan membagi periode yaitu sebelum reformasi (sebelum 1978) dan sesudah reformasi (sesudah 1978). Data yang digunakan adalah time series tahun 1952-1999. Donald dan Roberts (2002) selain memasukkan variabel pendidikan juga memasukkan variabel kesehatan dalam mengestimasi pertumbuhan ekonomi suatu negara dengan mengambil sampel 77 negara tediri dari 22 negara OECD dan 55 negara LDCs. Lin (2003) meneliti dampak pendidikan terhadap pertumbuhan ekonomi Taiwan selama periode 1965-2000. Penelitian mengenai dampak pengeluaran pendidikan terhadap human capital dilakukan oleh Gupta (1999) dengan menggunakan persamaan simultan, meneliti hubungan timbal balik (causality) antara pengeluaran pendidikan dan human capital. Al-Samarrai dan Zaman (2002) meneliti dampak penghapusan biaya pendidikan terhadap tingkat partisipasi siswa terutama pendidikan dasar dan menengah.

Studi yang menunjukkan hubungan negatif antara pengeluaran pemerintah dan pertumbuhan di antaranya: Barro dan Salla-i-Martin (1992) yang membagi pengeluaran pemerintah menjadi pengeluaran produktif dan tidak produktif. Pengeluaran produktif apabila pengeluaran tersebut mempunyai efek langsung terhadap pertumbuhan ekonomi. Kebanyakan studi mengenai hubungan antara pengeluaran pemerintah dengan pertumbuhan ekonomi mengasumsikan semua pengeluaran pemerintah bersifat produktif (Barro, 1990). Landau (1983) meneliti 27 negara berkembang menyimpulkan bahwa pengeluaran pemerintah yang besar terutama pengeluaran konsumsi justru akan menurunkan pertumbuhan pendapatan per kapita. Hasil yang sama ditemukan oleh Landau (1986) terhadap 65 negara berkembang. Devarajan dan Vinaya (1993) menemukan hubungan negatif dan tidak signifikan hubungan antara pengeluaran produktif dengan pertumbuhan. Sementara itu Lin (1994) menyatakan pengeluaran non-produktif mempunyai hubungan negatif dan tidak signifikan terhadap pertumbuhan di negara industri tetapi positif dan 
signifikan di negara berkembang. Hal ini terjadi karena pelayanan pemerintah yang bersifat non produktif di negara berkembang sebagian besar digunakan untuk konsumsi. Josaphat P Kweka dan Oliver Morrisey (1999) meneliti hubungan keduanya terhadap negara Tanzania periode 1965-1996. Hasil yang diperoleh bahwa pengeluaran pemerintah berdampak negatif terhadap pertumbuhan. Dampak negatif disebabkan karena tidak efisiennya pengeluaran pemerintah di Tanzania. Penelitian lain menunjukkan bahwa pengeluaran konsumsi pemerintah mempunyai dampak negatif terhadap pertumbuhan (Grier dan Tullock,1989, Barro,1991). Studi terhadap negara-negara maju juga menyimpulkan hasil yang sama seperti Hannson dan Henrekson (1994). Pada mayoritas studi, pengeluaran pemerintah total mempunyai efek negatif terhadap pertumbuhan (Romer,1990; Folster dan Henrekson,2001). Folster dan Henrekson mengatakan bahwa pada tingkat pengeluaran pemerintah yang rendah di negara miskin terutama untuk pengeluaran produktif dan rendah pula pajaknya, biasanya tidak efisien dalam pengumpulan pajak dan pengeluaran pemerintahnya.

Studi yang menunjukkan hubungan positif antara pengeluaran pemerintah dan pertumbuhan di antaranya: Ram (1986) dan Grossman (1988) menemukan hubungan positif antara pengeluaran pemerintah dengan pertumbuhan ekonomi. Diamond (1989) menyatakan bahwa pengeluaran sosial mempunyai hubungan positif yang signifikan dan pengeluaran investasi mempunyai efek negatif terhadap pertumbuhan ekonomi. Dampak tersebut sangat dipengaruhi oleh efisiensi penggunaan dana.

\section{B. Metode Penelitian}

Pendekatan penelitian yang digunakan adalah pendekatan kuantitatif yang diperkuat dengan menggunakan pendekatan kualitatif dalam analisis. Data yang digunakan dalam penelitian ini adalah data sekunder yang berasal dari Badan Pusat Statistik (BPS), dalam penelitian ini data yang di analisis secara kuantitatif adalah Data Pengeluaran Pemerintah untuk Pendidikan (EDEXP) dan data Produk Domestik Bruto (PDB)

Uji Kausalitas Granger dilakukan untuk mengetahui apakah suatu variable endogen dapat dapat diperlakukan sebagai variable eksogen. Kausalitas Granger dilakukan untuk mengetahui keterpengaruhan antar variable. Jika terdapat dua variable $X$ dan $Y$, maka apakah $\mathrm{X}$ menyebabkan $\mathrm{Y}$ atau $\mathrm{Y}$ menyebabkan $\mathrm{X}$ atau berlaku keduanya atau tidak ada hubungan keduanya. Variable $X$ menyebabkan variable $Y$ artinya berapa banyak nilai $Y$ pada periode sekarang dapat dijelaskan oleh nilai $Y$ pada periode sebelumnya dan nilai $X$ pada periode sebelumnya. Kausalitas Granger hanya menguji 
hubungan di antara variable dan tidak melakukan estimasi terhadap model. Untuk regresi bivariate diperoleh model:

$$
\begin{aligned}
& \mathrm{Yt}={ }_{0}+\mathrm{a}_{1} \mathrm{Y}_{\mathrm{t}-1}+\ldots+\mathrm{a}_{\mathrm{n}} \mathrm{Y}_{\mathrm{t}-\mathrm{n}}+\beta_{1} \mathrm{X}_{\mathrm{t}-1}+\ldots+\beta_{\mathrm{n}} \mathrm{X}_{\mathrm{t}-\mathrm{n}}+\varepsilon_{1} \\
& \mathrm{Xt}={ }_{0}+\mathrm{a}_{1} \mathrm{X}_{\mathrm{t}-1}+\ldots+\mathrm{a}_{\mathrm{n}} \mathrm{X}_{\mathrm{t}-\mathrm{n}}+\beta_{1} \mathrm{Y}_{\mathrm{t}-1}+\ldots+\beta_{\mathrm{n}} \mathrm{Y}_{\mathrm{t}-\mathrm{n}}+\varepsilon_{1}
\end{aligned}
$$

F-statistics adalah Wald statistics dengan hipotesis masing-masing persamaan:

$\beta_{1}=\beta_{2}=$ $=\beta_{n}=0$

Hipotesis null adalah

$\mathrm{H}_{0}=\mathrm{X}$ tidak Granger menyebabkan $\mathrm{Y}$ untuk regresi 1 dan $\mathrm{Y}$ tidak Granger menyebabkan $X$ untuk regresi 2 .

1. Jika $\beta_{1}=\beta_{2}=$ $=\beta_{\mathrm{n}} \neq 0$ untuk persamaan 1 dan $\beta_{1}=\beta_{2}=$ $=\beta_{n}=$ 0 untuk persamaan 2 , berarti $X$ Granger menyebabkan $Y$ dan tidak sebaliknya.

2. Jika $\beta_{1}=\beta_{2}=$ $=\beta_{n}=0$ untuk persamaan 1 dan $\beta_{1}=\beta_{2}=$ $=\beta_{n} \neq$ 0 untuk persamaan 2 , berarti $Y$ Granger menyebabkan $X$ dan tidak sebaliknya.

3. Jika $\beta_{1}=\beta_{2}=\ldots \ldots \ldots .=\beta_{n} \neq 0$ untuk persamaan 1 dan $\beta_{1}=\beta_{2}=\ldots \ldots \ldots .=\beta_{n} \neq$ 0 untuk persamaan 2 , berarti $X$ Granger menyebabkan $Y$ dan $Y$ menyebabkan $\mathrm{X}$.

4. Jika $\beta_{1}=\beta_{2}=$ $=\beta_{\mathrm{n}}=0$ untuk persamaan 1 dan $\beta_{1}=\beta_{2}=$ $=\beta_{\mathrm{n}}=$ 0 untuk persamaan 2 , berarti $X$ dan $Y$ tidak ada hubungan.

\section{Hasil Penelitian dan Pembahasan}

\section{Pengujian Akar-akar Unit ( Unit Root Test) Dan Derajat I ntegrasi}

Pengujian akar unit ini sering juga disebut dengan stationary stochastic process, karena pada prinsipnya uji tersebut dimaksudkan untuk mengamati apakah koefisien tertentu dari model otogresif yang ditaksir mempunyai nilai satu atau tidak. Dalam analisis time series, informasi tentang stasioneritas suatu data series merupakan hal yang sangat penting karena mengikutsertakan variabel yang nonstasioner ke dalam persamaan estimasi koefisien regresi akan mengakibatkan standard error yang dihasilkan jadi bias. Adanya bias ini akan menyebabkan kriteria konvensional yang biasa digunakan untuk menjustifikasi kausalitas antara dua variabel menjadi tidak valid. Artinya, estimasi regresi dengan menggunakan suatu variabel yang memiliki unit root (data nonstasioner) dapat menghasilkan kesimpulan (forecasting) yang tidak benar karena koefisien regresi penaksir tidak efisien.

Pada penelitian ini, uji stasioneritas dilakukan dengan menggunakan metode Augmented Dickey-Fuller Test (ADF). Uji stasioneritas ini didasarkan atas hipotesis nol variabel stokastik memiliki unit root. Dengan menggunakan model uji ADF test, hipotesis nol dan dasar pengambilan keputusan lainnya yang digunakan dalam uji ini 
didasarkan pada nilai kritis MacKinnon sebagai pengganti uji-t. Selanjutnya nisbah $\mathrm{t}$ tersebut dibandingkan dengan nilai kritis statistik pada t tabel ADF untuk mengetahui ada atau tidaknya akar-akar unit. Jika hipotesa diterima berarti variabel tersebut tidak stasioner, maka perlu dilakukan uji derajat integrasi. Uji derajat integrasi dimaksudkan untuk melihat pada derajat atau order diferensi ke berapa data yang diamati akan stasioner.

Tabel 1. Uji Akar Unit Variabel GDP

\begin{tabular}{|l|l|ll|r|}
\hline ADF Test Statistic & -4.109575 & $1 \%$ Critical Value* & -4.2324 \\
\hline & & $5 \%$ Critical Value & -3.5386 \\
\hline & & $10 \%$ Critical Value & -3.2009 \\
\hline *MacKinnon critical values for rejection of hypothesis of a unit root.
\end{tabular}

Pada uji stasioneritas variabel GDP sudah lolos dengan nilai kritis $5 \%$, yaitu nilai ADF 4,109575 dengan nilai kritis $-3,5386$ pada taraf signifikansi $95 \%$.

Tabel 2. Uji Akar Unit Variabel EDEXP

\begin{tabular}{|c|c|c|c|}
\hline ADF Test Statistic & -0.512827 & $1 \% \quad$ Critical Value* & -4.2324 \\
\hline & & $5 \% \quad$ Critical Value & -3.5386 \\
\hline & & $10 \%$ Critical Value & -3.2009 \\
\hline
\end{tabular}

Sedangkan pada uji stasioneritas variabel pengeluaran pendidikan (EDEXP) belum lolos dengan nilai kritis baik $10 \%, 5 \%$ maupun $1 \%$, yaitu dengan nilai ADF $-0,512827$ dengan nilai kritis $-4,2324,-3,5386$ maupun $-3,5386$. Apabila satu variabel tidak lolos uji akar unit pada tahap aras/level maka diperlukan uji lebih lanjut yaitu uji derajat integrasi.

Tabel 3. Uji Derajat Integrasi EDEXP

\begin{tabular}{|l|l|ll|l|}
\hline ADF Test Statistic & -3.039683 & $1 \%$ Critical Value* & -4.2412 \\
\hline & & $5 \%$ Critical Value & -3.5426 \\
\hline \multicolumn{3}{|r|}{ *MacKinnon critical values for rejection of hypothesis of a unit root. } \\
\hline
\end{tabular}


Pada Tabel 3 di atas menunjukkan variabel EDEXP belum juga lolos uji akar unit pada derajat integrasi pertama, meski dengan nilai kritis -3,2032 pada taraf signifikansi $90 \%$ pun karena nilai ADF statistiknya hanya $-3,039683$. Karena variabel EDEXP belum stasioner pada derajat integrasi pertama maka diperlukan uji selanjutnya yaitu uji derajat integrasi kedua.

Tabel 4: Uji Derajat Integrasi EDEXP

\begin{tabular}{|l|l|l|r|}
\hline ADF Test Statistic & -5.004179 & $1 \%$ Critical Value* & -4.2505 \\
\hline & & $5 \%$ Critical Value & -3.5468 \\
\hline & & $10 \%$ Critical Value & -3.2056 \\
\hline
\end{tabular}

Pada uji derajat integrasi kedua seperti ditunjukkan Tabel 4. Variabel EDEXP sudah lolos uji pada nilai kritis $1 \%,-42505$ dengan nilai ADF statistik $-5,004179$. Apabila kedua variabel sudah stasioner maka langkah selanjutnya dapat dilakukan.

\section{Penentuan Panjang Lag}

Sebelum melakukan uji kointegrasi perlu dilakukan penentuan panjang lag. Karena uji kointegrasi sangat peka terhadap panjang lag, maka penentuan lag yang optimal menjadi salah satu prosedur penting yang harus dilakukan dalam pembentukan model (Enders, 2004). Secara umum terdapat beberapa parameter yang dapat digunakan untuk menentukan panjang lag yang optimal, antara lain AIC (Akaike Information Criterion), SIC (Schwarz Information Criterion) dan LR (Likelihood Ratio).

Tabel 5. Penentuan Panjang Lag

\begin{tabular}{|c|c|c|c|c|}
\hline Nilai AIC & Lag ke-1 & Lag ke-2 & Lag ke-3 & Lag ke-4 \\
\hline AIC & $-2,369763$ & $-2,167784$ & $-2,263391$ & $-1,983301$ \\
\hline SC & $-2,113830$ & $-1,736840$ & $-1,653854$ & $-1,191541$ \\
\hline
\end{tabular}

Dari tabel 5 diatas menunjukkan bahwa pada lag atau kelambanan ke 4 mempunyai nilai baik AIC maupun SC yang terkecil yaitu -1,983301 dan -1,19154. 


\section{Uji Kointegrasi (Johansen's Cointegration Test)}

Kointegrasi merupakan kombinasi hubungan linear dari variabel-variabel yang nonstasioner dan semua variabel tersebut harus terintegrasi pada orde atau derajat yang sama. Variabel-variabel yang terintegrasi akan menunjukkan bahwa variabel tersebut mempunyai trend stokhastik yang sama dan selanjutnya mempunyai arah pergerakan yang sama dalam jangka panjang. Dalam penelitian ini, pengujian kointegrasi menggunakan metode Johansen's Multivariate Cointegration Test. Diawali dengan pendefinisian suatu vektor dari $n$ potensial peubah endogen $Z t$. $Z t$ diasumsikan sebagai suatu sistem VAR yang tidak terestriksi dan memiliki sampai klags:

$\mathrm{Zt}=\mathrm{A} 1 \mathrm{Zt}-1+\ldots \ldots \ldots+\mathrm{Ak} \mathrm{Zt}-\mathrm{k}+\Phi \mathrm{Dt}+\mu+\varepsilon \mathrm{t}$

Di mana: $A i$ adalah $n \times n$ koefisien matriks, $\mu$ adalah konstanta, $D t$ adalah peubah boneka musiman yang ortogonal terhadap konstanta $\mu$ dan $\varepsilon$ t diasumsikan independen dan secara identik berdistribusi berdasarkan proses Gaussian. Persamaan (3.8) dapat diformulasikan kembali ke dalam bentuk vector error correction (VECM) dengan mengurangkan $\mathrm{Zt}-1$ dari kedua sisi persamaan:

$$
\Delta \mathrm{Zt}=\Gamma 1 \Delta \mathrm{Zt}-1+\ldots \ldots . .+\Gamma \mathrm{k}-1 \Delta \mathrm{Zt}-\mathrm{k}+1+\Pi \mathrm{Zt}-\mathrm{k}+\Phi \mathrm{Dt}+\mu+\varepsilon \mathrm{t}
$$

Di mana, $\Gamma \mathrm{i}=-(\mathrm{I}-\mathrm{A} 1-\ldots . . . \mathrm{Ai}),(\mathrm{i}=1, \ldots, \mathrm{k}-1)$, dan $\Pi=-(\mathrm{I}-\mathrm{A} 1-\ldots$ - Ak).

Berdasarkan panjang lag di atas, kami melakukan uji kointegrasi untuk mengetahui apakah akan terjadi keseimbangan dalam jangka panjang, yaitu terdapat kesamaan pergerakan dan stabilitas hubungan di antara variabel-variabel di dalam penelitian ini atau tidak. Dalam penelitian ini, uji kointegrasi dilakukan dengan menggunakan metode Johansen's Cointegration Test seperti terlihat pada Tabel 6.

Berdasarkan Tabel 6 dapat dilihat bahwa nilai LR lebih kecil dari critical value dengan tingkat signifikansi $1 \%$ dan $5 \%$. Hal ini berarti hipotesis nol yang menyatakan bahwa tidak ada kointegrasi diterima dan hipotesis alternatif yang menyatakan bahwa ada kointegrasi dapat ditolak. Berdasarkan analisis ekonometrik di atas dapat dilihat bahwa di antara kedua variabel dalam penelitian ini, tidak terdapat berkointegrasi pada tingkat signifikansi $1 \%$ dan $5 \%$. Dengan demikian, dari hasil uji kointegrasi mengindikasikan bahwa di antara GDP dan pengeluaran pendidikan tidak memiliki hubungan stabilitas/keseimbangan dan kesamaan pergerakan dalam jangka panjang. Dengan kalimat lain, dalam setiap periode jangka pendek, seluruh variabel cenderung tidak saling menyesuaikan, untuk mencapai ekuilibrium jangka panjangnya. 
Tabel 6. Uji Kointegrasi

Date: 10/11/11 Time: 10:19

Sample: 19692008

Included observations: 38

Test assumption: Linear deterministic trend in the data

Series: LGDP LEDEXP

Lags interval: 1 to 1

\begin{tabular}{ccccc}
\hline \hline Eigenvalue & $\begin{array}{c}\text { Likelihood } \\
\text { Ratio }\end{array}$ & $\begin{array}{c}\text { 5 Percent } \\
\text { Critical Value }\end{array}$ & $\begin{array}{c}\text { 1 Percent } \\
\text { Critical Value }\end{array}$ & $\begin{array}{c}\text { Hypothesized } \\
\text { No. of CE(s) }\end{array}$ \\
\hline \hline 0.159486 & 7.891333 & 15.41 & 20.04 & None \\
0.033356 & 1.289138 & 3.76 & 6.65 & At most 1 \\
\hline \hline
\end{tabular}

$*(* *)$ denotes rejection of the hypothesis at $5 \%(1 \%)$ significance level L.R. rejects any cointegration at $5 \%$ significance level

Unnormalized Cointegrating Coefficients:

\begin{tabular}{cl}
\hline \hline LGDP & LEDEXP \\
-0.957436 & 0.853049 \\
0.150662 & 0.078338 \\
\hline \hline
\end{tabular}

Normalized Cointegrating Coefficients: 1 Cointegrating Equation(s)

\begin{tabular}{ccc}
\hline \hline LGDP & LEDEXP & C \\
1.000000 & -0.890972 & -5.496424 \\
& $(0.08268)$ & \\
& & \\
Log likelihood & 50.54332 & \\
\hline
\end{tabular}

\section{Uji Kausalitas Granger}

Dalam pengujian kausalitas ini dilakukan dengan menggunakan model multivariat VAR yang dilakukan secara bersamaan. Setiap persamaan dalam VAR diuji dalam distribusi Wald Chi-Squares atau biasa dinotasikan $x^{2}-$ Wald. Setiap variabel dipertukarkan dari variabel endogen menjadi variabel eksogen untuk diuji hubungan kausalitas. Hasil perhitungan statistik $\mathrm{X}^{2}$ - Wald menunjukkan signifikansi gabungan 
(joint significance) dari variabel endogen bedakala dalam persamaan VAR. Tabel $7 \mathrm{di}$ bawah ini adalah hasil pengujian kausalitas dengan univariat VAR.

Tabel 7. Uji Kausalitas Granger

Pairwise Granger Causality Tests

Date: 10/11/11 Time: 10:25

Sample: 19692008

Lags: 3

\begin{tabular}{lccc}
\hline \hline Null Hypothesis: & Obs & F-Statistic & Probability \\
\hline \hline LEDEXP does not Granger Cause LGDP & 37 & 3.44598 & 0.02896 \\
LGDP does not Granger Cause LEDEXP & & 3.17218 & 0.03846 \\
\hline \hline
\end{tabular}

Berdasarkan uji hubungan kausalitas dengan metode Granger Causality didapati hasil bahwa terdapat hubungan dua arah (kausalitas) antara pengeluaran pendidikan (EDEXP) dan pertumbuhan ekonomi (GDP). Hal ini mengindikasikan bahwa pergerakan GDP mendorong anggaran pendidikan naik di Indonesia, di samping itu anggaran pendidikan juga akan meningkatkan GDP.

\section{Model Empiris dalam VAR}

Model VAR yang dikembangkan oleh Sims (1980) dalam (Enders, 2004) mengasumsikan bahwa seluruh variabel dalam persamaan simultan adalah variabel endogen. Asumsi ini diterapkan karena seringkali penentuan variabel eksogen dalam persamaan simultan bersifat subjektif. Dalam VAR, semua variabel tak bebas dalam persamaan juga akan muncul sebagai variabel bebas dalam persamaan yang sama. Pendekatan VAR merupakan permodelan setiap variabel endogen dalam sistem sebagai fungsi dari lag semua variabel endogen dalam sistem. Berdasarkan standard form dalam model VAR, bentuk umum untuk kasus multivariate (Enders, 2004) adalah sebagai berikut:

$Y t=A o+A 1 Y t-1+A 2 Y t-2+\ldots+A p Y t-p+\varepsilon t$

dimana: Yt : vektor ( $\mathrm{n} \times 1)$ yang berisi $\mathrm{n}$ dari masing-masing variabel dalam VAR

Ao : vektor $(\mathrm{nx} 1)$ intersep

Ai : koefisien matrik (nxn)

$\varepsilon t$ : vektor $(\mathrm{nx} 1)$ dari error term

Berdasarkan bentuk umum di atas, model penelitian dengan menggunakan model standard VAR menjadi sebagai berikut: 


$$
\left[\begin{array}{l}
L G D P_{t} \\
L E D E X P_{t}
\end{array}\right]=\left[\begin{array}{l}
\alpha_{10} \\
\alpha_{20}
\end{array}\right]+\left[\begin{array}{ll}
a_{11}(L) & a_{12}(L) \\
a_{21}(L) & a_{22}(L)
\end{array}\right]\left[\begin{array}{l}
L G D P_{t} \\
L E D E X P_{t}
\end{array}\right]+\left[\begin{array}{l}
\varepsilon_{1 t} \\
\varepsilon_{2 t}
\end{array}\right]
$$

Di mana: LGDP = Logaritma natural Gross Domestic Product dan LEDEXP = Logaritma natural Pengeluaran Pendidikan. Bentuk VAR di atas merupakan bentuk VAR biasa yang bebas restriksi digunakan jika data stasioner di tingkat level. Variasi bentuk VAR biasanya terjadi akibat perbedaan derajat integrasi data variabelnya, yaitu dikenal dengan nama VAR in leve/ dan VAR in difference. VAR leve/ digunakan ketika data penelitian memiliki bentuk stasioner dalam level. Jika data tidak stasioner dalam level namun tidak memiliki (secara teoritis tidak memerlukan keberadaan) hubungan kointegrasi, maka estimasi VAR dilakukan dalam bentuk difference.

Tabel 8. Hasil Estimasi VAR

\begin{tabular}{lll}
\hline \hline & LGDP & LEDEXP \\
\hline \hline LGDP(-1) & 1.140023 & 0.711616 \\
& $(5.95327)$ & $(1.90418)$ \\
& & \\
LGDP(-2) & 0.142457 & -0.278393 \\
& $(0.51955)$ & $(-0.52026)$ \\
& & \\
LGDP(-3) & -0.472850 & -0.121535 \\
& $(-1.70936)$ & $(-0.22513)$ \\
& & \\
LGDP(-4) & 0.027530 & 0.010621 \\
& $(0.12267)$ & $(0.02425)$ \\
& & \\
LEDEXP(-1) & 0.018348 & 0.577039 \\
& $(0.18592)$ & $(2.99614)$ \\
& & \\
LEDEXP(-2) & -0.078240 & -0.042113 \\
& $(-0.69236)$ & $(-0.19096)$ \\
\hline \hline
\end{tabular}




\begin{tabular}{lll}
\hline \hline & LGDP & LEDEXP \\
\hline \hline & & \\
LEDEXP(-3) & 0.300309 & 0.181434 \\
& $(2.59736)$ & $(0.80409)$ \\
& & \\
LEDEXP(-4) & -0.072748 & 0.022286 \\
& $(-0.63363)$ & $(0.09947)$ \\
& & \\
C & 0.790889 & -1.865311 \\
& $(1.14482)$ & $(-1.38354)$ \\
R-squared & 0.988421 & 0.963957 \\
Adj. R-squared & 0.984991 & 0.953277 \\
Sum sq. resids & 0.243338 & 0.926766 \\
S.E. equation & 0.094934 & 0.185269 \\
F-statistic & 288.1098 & 90.26219 \\
Log likelihood & 38.86103 & 14.79054 \\
Akaike AIC & -1.658946 & -0.321697 \\
Schwarz SC & -1.263067 & 0.074183 \\
Mean dependent & 11.74013 & 7.005869 \\
S.D. dependent & 0.774893 & 0.857113 \\
Determinant Residual Covariance & 0.000174 \\
Log Likelihood & & 53.69941 \\
Akaike Information Criteria & -1.983301 \\
Schwarz Criteria & & -1.191541 \\
\hline \hline
\end{tabular}

Uji parsial masing-masing variabel independen dengan menggunakan uji-t dimaksudkan untuk mengetahui hubungan antar variabel-variabel dalam model penelitian. Dari hubungan antar variabel tersebut dapat dianalisis mekanisme transmisinya, sehingga dapat diketahui apakah mekanisme tersebut selaras dengan hipotesis yang diambil sebelumnya dan konsisten dengan teori. Dalam pengujian parsial menggunakan uji t dipakai derajat kepercayaan (df) $90 \%$ untuk dua sisi, uji ini bertujuan menetapkan signifikansi hubungan setiap variabel independen terhadap variabel dependen. Pada model penelitian diperoleh 5 hubungan antar variabel yang lolos uji t seperti terangkum dalam tabel 9 di bawah ini: 
Tabel 9. Hubungan Antar Variabel

\begin{tabular}{|c|c|}
\hline Dengan variabel lag sendiri & Dengan variabel lag lain \\
\hline $\mathrm{LGDP}(-1) \rightarrow \mathrm{LGDP}$ & $\mathrm{LGDP}(-1) \rightarrow \mathrm{LEDEXP}$ \\
$\mathrm{LGDP}(-3) \rightarrow \mathrm{LGDP}$ & $\mathrm{LEDEXP}(-3) \rightarrow \mathrm{LGDP}$ \\
$\mathrm{LEDEXX}(-1) \rightarrow \mathrm{LEDEXP}$ & \\
\hline
\end{tabular}

Dalam Tabel 9 di atas, terdapat dua kolom, pertama menunjukkan hubungan antara variabel kelambanan dengan variabel dependennya sendiri, sedangkan kolom kedua menunjukkan hubungan antara variabel kelambanan dengan variabel dependen lainnya. Dalam analisis ini yang menjadi perhatian adalah hubungan antar variabel kelambanan dengan variabel dependen lainnya, sehingga peran kolom kedua di atas lebih penting. Apabila dilihat hubungan dalam satu variabel, variabel LGDP mempengaruhi LGDP pada bulan ke-3 dan ke-1. Dapat dijelaskan bahwa variabel GDP membutuhkan waktu untuk mempengaruhi GDP tahun berikutnya. Sedangkan variabel EDEXP dapat langsung mempengaruhi pengeluaran pendidikan tahun berikutnya secara langsung.

\section{Variabel GDP $\rightarrow \operatorname{LGDP(-3)\uparrow \rightarrow LGDP(-1)\uparrow \rightarrow LGDP\uparrow }$}

Dari skema di atas dapat dijelaskan bahwa naiknya GDP pada kelambanan ke 3 akan meningkatkan GDP pada kelambanan ke 1, artinya dibutuhkan waktu 2 tahun untuk mengetahui dampak naiknya pertumbuhan nekonomi terhadap pertumbuhan ekonomi pada tahap selanjutnya.

\section{Variabel pengeluaran Pendidikan $\rightarrow$ LEDEXP(-1) $\uparrow$ LEDEXP $\uparrow$}

Sedangkan variabel pengeluaran pendidikan dapat mempengaruhi kenaikan anggaran pendidikan pada tahun berikutnya. Artinya apabila pada tahun ini pemerintah meningkatkan pengeluaran pendidikannya dalam APBN maka tahun berikutnya pemerintah dapat langsung meningkatkan lagi anggaran pendidikan tanpa menunggu, sama dengan tahun sebelumnya.

Transmisi GDP terhadap pengeluaran Pendidikan

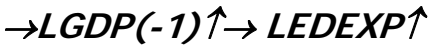


Dapat dijelaskan bahwa ketika pendapatan pemerintah naik yang tercermin dari naiknya GDP, maka untuk tahun anggaran berikutnya pemerintah dapat secara langsung mengalokasikan peningkatan anggaran pendidikan pada RAPBN tahun berikutnya tergantung dari politik anggaran. Artinya pengeluaran anggaran pendidikan sangat tergantung dari keuangan pemerintah, apabila pertumbuhan ekonomi baik pendapatan nasional surplus maka pemerintah akan memperoleh pendapatan dari pajak misalnya sehingga mempunyai alokasi anggaran yang lebih bebas dalam menentukan pos anggaran yang dikehendaki. Beberapa tahun terakhir pemerintah terus meningkatkan anggaran pendidikan sampai mencapai $20 \%$ dari APBN seiring dengan pertumbuhan ekonomi.

\section{Transmisi pengeluaran Pendidikan terhadap $\rightarrow$ LEDEXP(-3) $\uparrow \rightarrow$ LGDP $\uparrow$}

Sesuai dengan teori yang menyatakan bahwa pendidikan tidak dapat mempengaruhi ekonomi dalam jangka pendek setidaknya dalam penelitian ini menguatkan teori tersebut. Pendidikan baru mempengaruhi pertumbuhan ekonomi setelah tahun ke-3. Apabila pemerintah meningkatkan anggaran pendidikan maka baru 3 tahun ke depan akan meningkatkan GDP.

Pendidikan memiliki daya dukung yang representatif atas pertumbuhan ekonomi. Tyler mengungkapkan bahwa pendidikan dapat meningkatkan produktivitas kerja seseorang, yang kemudian akan meningkatkan pendapatannya. Peningkatan pendapatan ini berpengaruh pula kepada pendapatan nasional negara yang bersangkutan, untuk kemudian akan meningkatkan pendapatan dan taraf hidup masyarakat berpendapatan rendah. Sementara itu Jones melihat pendidikan sebagai alat untuk menyiapkan tenaga kerja terdidik dan terlatih yang sangat dibutuhkan dalam pertumbuhan ekonomi suatu negara. Jones melihat, bahwa pendidikan memiliki suatu kemampuan untuk menyiapkan siswa menjadi tenaga kerja potensial, dan menjadi lebih siap latih dalam pekerjaannya yang akan memacu tingkat produktivitas tenaga kerja, yang secara langsung akan meningkatkan pendapatan nasional. Menurutnya, korelasi antara pendidikan dengan pendapatan tampak lebih signifikan di negara yang sedang membangun.

Intervensi pendidikan terhadap ekonomi merupakan upaya penyiapan pelakupelaku ekonomi dalam melaksanakan fungsi-fungsi produksi, distribusi, dan konsumsi. Intervensi terhadap fungsi produksi berupa penyediaan tenaga kerja untuk berbagai tingkatan yaitu top, midle, dan low management, atau secara ekstrem tenaga kerja krah biru dan krah putih. Di samping tenaga kerja, juga pendidikan mengintervensi produksi untuk penyediaan entrepreneur tangguh yang mampu mengambil risiko 
dalam inovasi teknologi produksi. Bentuk intervensi lain yaitu menciptakan teknologi baru dan menyiapkan orang-orang yang menggunakannya. Program-program perluasan produksi melalui intensifikasi dan rasionalisasi merupakan salah satu wujud nyata dari peran pranata pendidikan atas fungsi produksi ini. Intervensi terhadap fungsi distribusi adalah melalui pengembangan research and development produk yang sesuai dengan kebutuhan dan keinginan masyarakat atau konsumen. Intervensi terhadap fungsi konsumsi dilakukan melalui peningkatan produktivitas kerja yang akan mendorong peningkatan pendapatan. Peningkatan pendapatan ini akan mendorong pada peningkatan fungsi konsumsi, yang ditunjukan dengan meningkatnya jumlah tabungan yang berasal dari pendapatan yang disisihkan. Tabungan ini akan menjadi investasi kapital yang tentunya akan lebih mempercepat laju pertumbuhan ekonomi suatu negara.

\section{Kesimpulan}

1. Dari hasil uji kausalitas Granger dapat disimpulkan bahwa adanya hubungan kausalitas antara pertumbuhan ekonomi (GDP) dan pengeluaran pendidikan (EDEXP) keduanya saling mempengaruhi. GDP mempengaruhi EDEXP dan EDEXP juga mempengaruhi GDP. Hal itu ditunjukkan oleh nilai $F$ statistik untuk variabel yang menyatakan GDP tidak menyebabkan Granger mempengaruhi EDEXP sebesar 3.44598 lebih besar dari nilai probabilitasnya 0,02896. Sehingga hipotesis yang menyatakan GDP tidak mempengaruhi EDEXP ditolak, GDP akan mempengaruhi EDEXP. Sedangkan nilai $F$ statistik untuk variabel yang menyatakan EDEXP tidak menyebabkan Granger mempengaruhi GDP sebesar 3.17218 lebih besar dari nilai probabilitasnya 0,03846. Sehingga hipotesis yang menyatakan EDEXP tidak mempengaruhi GDP juga ditolak, EDEXP akan mempengaruhi GDP.

2. Apabila hubungan kausalitas sudah diketahui, maka berikutnya dalah mengetahui mekanisme transmisinya dengan menggunakan analisis Vector Autoregressive (VAR). Dalam analisis VAR ditunjukkan bahwa meskipun kedua variabel mempunyai hubungan kausalitas, namun dengan kecepatan pengaruh yang berbeda. GDP dapat langsung mempengaruhi peningkatan anggaran pendidikan pada tahun berikutnya sedangkan pengeluaran pendidikan baru akan mempengaruhi pertumbuhan ekonomi 3 tahun berikutnya.

Berdasarkan temuan penelitian tersebut di atas dapat diajukan beberapa saran sebagai berikut: 
1. Pemerintah sebaiknya terus meningkatkan pengeluaran pendidikannya, karena dari kedua variabel, variabel EDEXP dapat dipengaruhi oleh pemerintah. Baik dalam jangka pendek maupun panjang pendidikan merupakan faktor terpenting bagi kemajuan bangsa. Dalam jangka pendek anggaran pemerintah dalam sektor pendidikan akan menyebabkan multiplier effect yang besar pada gilirannya juga akan mempengaruhi pertumbuhan ekonomi.

2. Pengaruh pendidikan sebagai investasi modal manusia memang berlaku dalam jangka panjang, naiknya produktifitas tenaga kerja dan teknologi sebagai proksi dari hasil investasi pendidikan akan meningkatkan pertumbuhan ekonomi secara riil. Jadi kedua pengaruh jangka pendek dan jangka panjang saling mempengaruhi pertumbuhan ekonomi dan GDP.

\section{Daftar Pustaka}

Al-Samarai, S. 2002. The Changing Distribution of Public Education Expenditure in Malawi. Africa Region Working Papers Series 29.

Barata, Atep Adaya, 2004. Keluasan Pengelolaan Keuangan Negara, Elex Media Komputindo, Jakarta.

Barro, R. J. and Sala-i-Martin, X. 1995. Economic Growth. McGraw-Hill. New York.

BPS-Bappenas-UNDP. 2009. Toward A New Concencus: Democracy and Human Development Report.

Dickey, D.A and Fuller, W.A. 1981. Likelihood Ratio Statistics for Autoregressive Time Series with a Unit Root. Econometrica. Vol.49.

Donald, M. S, Robert, J. 2002. Growth and Multiple Forms of Human Capital in Augmented Solow model: A Panel Data Investigation. Economics Letters. 74:271276.

Easterly, William. 2001. The Economic Quest for Growth, MIT Press.

Eckstein, Z and Zilcha, I. 1994. The Effect of Compulsary Schoolling on Growth, Income Distribution, and Welfare. Journal of Public Economics 54:339-359. Columbia University Press.

Engle, R. F and Granger, C. W. J. 1987. Cointegration and Error Corection: Representation, Estimation and Testing. Econometrica. Vol.11:251-276.

Gujarati, D. 1999. Essential of Econometrics. MacGraw-Hill Book Co. $2^{\text {nd }}$ edition.

Gujarati, D. 2003. Basic Econometrics. MacGraw-Hill Book Co. $4^{\text {th }}$ edition.

Gupta, K. 1999. Public Expenditure on Education and Literacy Levels. A Comparative Study. State University at Stony Brook. 
Landau, Daniel L. 1986. Government and Economic Growth in The Less Developed Countries: An Empirical Study for 1960-1980, ED \& CS

Lin, Steven AY. 1994. Government Spending and Economic Growth, IDEAS.

Mankiw, N. G. Romer. D, and Weil, N.D. 1992. A Contribution to the Empirics of Economic Growth. Quarterly Journal of Economics. Vol. 107 Issue 2:407-437.

Musgrave, R. A. 1969. Fiscal System. Yale University Press. New Heaven.

Ranis, G, Stewart, F and Ramirez, A. 2000. Economic growth and Human Development. World Development vol.28 No.2.

Solow, R. 1956. A Contribution to the Theory of Economic Growth. Quarterly Journal of Economics 70:65-94.

Suryadi, A. 2001. Anggaran Pendidikan, Agenda yang Terabaikan. Kompas.28 Februari.

Sylwester, K. 2002. Can Education Expenditures Reduce Income Equality. Economics of Education Review 21.

Sylwester, K.A. 2002. Model of Public Education and Income Inequality, JSTOR

Wagner, R. E and Weber, W. E. 1977. Wagner's Law, Fiscal Institutionts, and The Growth of Government. National Tax Journal. Vol 30:59-58. 